\title{
In vitro efficacy of several disinfectants against Salmonella enterica serovar Enteritidis and Escherichia coli strains from poultry
}

\author{
Eficácia de vários desinfetantes in vitro contra cepas de Salmonella enterica \\ serovar Enteritidis e Escherichia coli aviária
}

\begin{abstract}
Sonia Martínez-Martínez ${ }^{\mathrm{I}}$ Sheila Yubero-Delgado ${ }^{\mathrm{I}}$ Elías-Fernando Rodríguez-Ferri ${ }^{\mathrm{I}}$ Rafael FrandolosoII Álvaro Álvarez-Estrada ${ }^{I}$ César-Bernardo Gutiérrez-Martín ${ }^{{ }^{*}}$
\end{abstract}

\section{ABSTRACT}

The efficacy of 28 individual or blended disinfectants against avian Salmonella enterica serovar Enteritidis and Escherichia coli strains was determined. An in vitro test in the presence and absence of serum as source of organic material was conducted. Povidone-iodine (releasing 1\% available iodine), $1 \%$ potassium permanganate, $70 \%$ ethanol, $2 \%$ chlorhexidine digluconate and three commercial formulations based on quaternary ammonium compounds + formaldehyde or cresol derivates were the most effective against all strains tested and reduced bacterial counts by more than $10^{6}$ times $\left(6-\log _{10}\right)$ regardless of the presence of organic matter. These commercial compounds as well as ethanol and chlorhexidine among the individual substances tested might be helpful in the adoption of environmental control measures against these two enterobacteria in poultry industry.
\end{abstract}

- NOTE
Key words: Salmonella enterica serovar Enteritidis, Escherichia coli, disinfection, suspension test, poultry industry.

RESUMO

A eficácia de 28 desinfetantes individuais ou combinados sobre cepas de Salmonella enterica serovar Enteritidis e Escherichia coli foi determinada. Um teste in vitro em presença e ausência de soro como fonte de matéria orgânica foi realizado. Iodopovidona (contendo $1 \%$ de iodo ativo), permanganato de potássio a $1 \%$, etanol a $70 \%$, digliconato de clorexidina e três formulações comerciais, baseadas em compostos de amônia quaternária + formaldeído ou em derivados de cresóis, foram mais eficazes contra as cepas bacterianas testadas, reduzindo em mais $10^{6}$ vezes (6log) a contagem bacteriana, independente da presença de matéria orgânica. Esses compostos comerciais, bem como o etanol e a clorexidina entre as substâncias químicas individuais avaliadas, podem ser úteis para a implementação de medidas de controle ambiental contra estas duas enterobacterias de importância para a indústria aviária.

Palavras-chave: Salmonella enterica serovar Enteritidis, Escherichia coli, desinfetantes, suspensão, prova de suspensão, indústria aviária.

The intensive poultry industry consistently applies an all-in, all-out system with the aim of minimizing infection pressure and targeting specific organisms such as Salmonella enterica serovar Enteritidis (S. enteritidis) and Escherichia coli, which are two of the pathogens that cause heavy economic losses worldwide. The prevention and control of avian diseases largely relies on biosecurity, especially in case of environmentally-robust zoonotic enteric pathogens (MARIN et al., 2009; JOHNSON et al., 2012). Disinfectants are important components of a biosecurity program and combined with antimicrobial agents and food preservatives are used to reduce or eliminate environmental contamination. Disinfectants are employed during production breaks as a routine part of the management of poultry farms. The activity of 16 individual disinfectants and 12 commercial formulations against $\boldsymbol{S}$. enteritidis and $\boldsymbol{E}$. coli strains are described, including those used

\footnotetext{
'Departamento de Sanidad Animal, Microbiología e Inmunología, Facultad de Veterinaria, Universidad de León, 24007, León, España. E-mail: cbgutm@unileon.es. "Corresponding author

ILaboratório de Microbiologia e Imunologia Avançada, Faculdade de Agronomia e Medicina Veterinária, Universidade de Passo Fundo (UPF), Passo Fundo, RS, Brasil. 
routinely in avian industry for cleansing. A wellestablished in vitro suspension test was performed in this study (GUTIÉRREZ et al., 1995).

The following samples were tested: S. enteritidis ATCC 13076 reference strain, $\boldsymbol{S}$. enteritidis Le-01 field strain (isolated from a salmonellosis outbreak that occurred in egglaying hens in Castilla y León, Spain, in 2011), Escherichia coli $\mathrm{C}_{12} \mathrm{P}_{19}$ serogroup O91, and $\boldsymbol{E}$. coli $\mathrm{C}_{12} \mathrm{P}_{17}$, serogroup $\mathrm{O} 102$ (isolated respectively from egg-laying hens presenting clinical signs of diarrhea in Segovia and Madrid, Spain, 2010). These organisms were recovered in TSA agar (Biolife) at $37^{\circ} \mathrm{C}$ for $24 \mathrm{~h}$, and then inoculated onto the same conditions. Cells were suspended in either sterile saline solution (SS) or undiluted sterile bovine fetal serum (BFS) (Oxoid) to reach $10^{9}$ $\mathrm{CFU} \mathrm{ml} \mathrm{m}^{-1}$. The 12 commercial formulations were CR-36-Mural (undiluted), Darodor-9000 (1/5 v/v), Limoseptic $(1 / 400 \mathrm{v} / \mathrm{v})$, Limoseptic Plus (1/400 v/v), Limoseptic SF (1/400 v/v), Totalcide $(1 / 400$ $\mathrm{v} / \mathrm{v})$, Virkon S (1/200 w/v), Proxitane $15(1 / 100$ v/v), DVA 2000 (undiluted), UCI 414 (undiluted), Daronit $4000(1 \% \mathrm{v} / \mathrm{v})$ and Polimorfo (1/200 $\mathrm{v} / \mathrm{v})$. Dilutions were carried out according to the instruction of the manufacturers: José Collado S.A. (numbers 1 to 5 and 9 to 12), Bio-Genetic (number 6), Bayer (number 7) and Solvay Chimie (number 8). The 16 individual disinfectants tested were chloramine-T $(0.4 \% \mathrm{w} / \mathrm{v})$, sodium hypochlorite $(0.5 \% \mathrm{w} / \mathrm{v})$, povidone-iodine and iodophor $(1 \%$ and $0.1 \%$ available iodine, respectively), $\mathrm{H}_{2} \mathrm{O}_{2}$ $(3 \% \mathrm{v} / \mathrm{v}), \mathrm{KMnO}_{4}(1 \% \mathrm{w} / \mathrm{v})$, benzalkonium and cetylpiridinium chlorides $(0.02 \%$ and $0.1 \% \mathrm{w} / \mathrm{v}$, respectively), ethanol and isopropanol $(70 \% \mathrm{v} / \mathrm{v})$, chlorhexidine digluconate $(2 \% \mathrm{v} / \mathrm{v})$, formaldehyde $(3.7 \% \mathrm{v} / \mathrm{v})$, phenol $(5 \% \mathrm{w} / \mathrm{v})$, phosphoric acid $(0.45 \% \quad \mathrm{v} / \mathrm{v})$, zinc sulphate $(0.25 \% \mathrm{w} / \mathrm{v})$ and thimerosal $(0.1 \mathrm{w} / \mathrm{v})$. Sterile tap water at $\mathrm{pH} 7.0$ was used as diluent.

Controls for each test were mixed with $0.9 \mathrm{ml}$ of sterile tap water instead of disinfectant. Reactions were performed by mixing $0.1 \mathrm{ml}$ of each S. enteritidis or $\boldsymbol{E}$. coli suspensions $\left(10^{9} \mathrm{CFU} \mathrm{\textrm {ml } ^ { - 1 }}\right.$ of SS previously adjusted by spectrophotometry) with $0.9 \mathrm{ml}$ of each disinfectant. After $1 \mathrm{~min}$ of contact at room temperature (GUTIÉRREZ et al., 1995; GUTIÉRREZ MARTÍN et al., 2011), 0.1ml of the mixture was removed and immediately diluted 100-times in SS in order to stop disinfectant action. The samples were subjected to further tenfold dilutions (until $\left.10^{-7}\right)$, and were spread $(0.1 \mathrm{ml}$ ) on TSA agar in triplicate and incubated as described above. The conditions for suspension tests with undiluted BFS were the same, but using $0.1 \mathrm{ml}$ of strains suspended in this organic matter instead of SS. Each test was carried out in triplicate, using a newly prepared dilution of each disinfectant and a fresh culture suspension. Disinfectant activity was determined by comparing growth on the control and disinfectant plates, and was reported as the mean \pm standard deviation log reduction in CFU per $\mathrm{ml}$. Each product was tested for its capacity to cause up to $6-\log _{10}(99.9999 \%)$ reduction in CFU of strains (maximal level of detection). At least a 3-log decrease (99.9\% reduction in CFU) was regarded as the minimal acceptable effective value (GUTIÉRREZ et al., 1995).

Formulations 1, 2 and 10 were extremely effective against the two $\boldsymbol{S}$. enteritidis strains tested with more than 6-log reductions $(99.9999 \%$ effectiveness). Compounds 4 to 9 were also highly active with SS, but their effectiveness was reduced by BFS (Figures 1a and b). Formulation 3 was effective under all conditions tested, but a $6-\log _{10}$ reduction was only seen for ATCC 13076 strain + $\mathrm{SS}$, while compound 11 was exclusively active to this same strain with SS (Figure 1a). Povidoneiodine, potassium permanganate, bezalkonium and cetylpiridinium chlorides, ethanol, chlorhexidine digluconate, phenol, isopropanol and formaldehyde were highly effective against S. enteritidis strains (more than 6-log reductions), while chloramine-T was only active against ATCC 13076 strain + SS. Remaining chemical agents were ineffective $\left(<3-\log _{10}\right)$.

Commercial compounds exhibited higher efficacies to $\boldsymbol{E}$. coli than to $\boldsymbol{S}$. enteritidis strains. Formulations 3, 5 and 6 showed the highest reduction with SS $\left(>6-\log _{10}\right)$; whereas, their activity decreased by BFS. Limoseptic Plus was successful against four strains, but its activity was reduced by BFS, while Virkon S (Figures 1b, c \& d) was inactive against $\mathrm{C}_{12} \mathrm{P}_{19}$ strain + BFS (Figure 1c). Similar to $\boldsymbol{S}$. enteritidis, formulations 11 and 12 were ineffective to $\boldsymbol{E}$. coli. However, $\boldsymbol{E}$. coli strains were more resistant to individual disinfectants than $\boldsymbol{S}$. enteritidis. Namely, only povidone-iodine, potassium permanganate, ethanol and chlorhexidine digluconate exhibited high efficacy $\left(>6-\log _{10}\right)$ against this bacterial species in comparison to the seven agents showing this maximal activity to $\boldsymbol{S}$. enteritidis. Although with lower efficacies, cetylpiridinium chloride, formaldehyde and phenol were also active (Figures $1 \mathrm{c}$ and d) to $\boldsymbol{E}$. coli strains, while isopropanol was only effective with SS. 

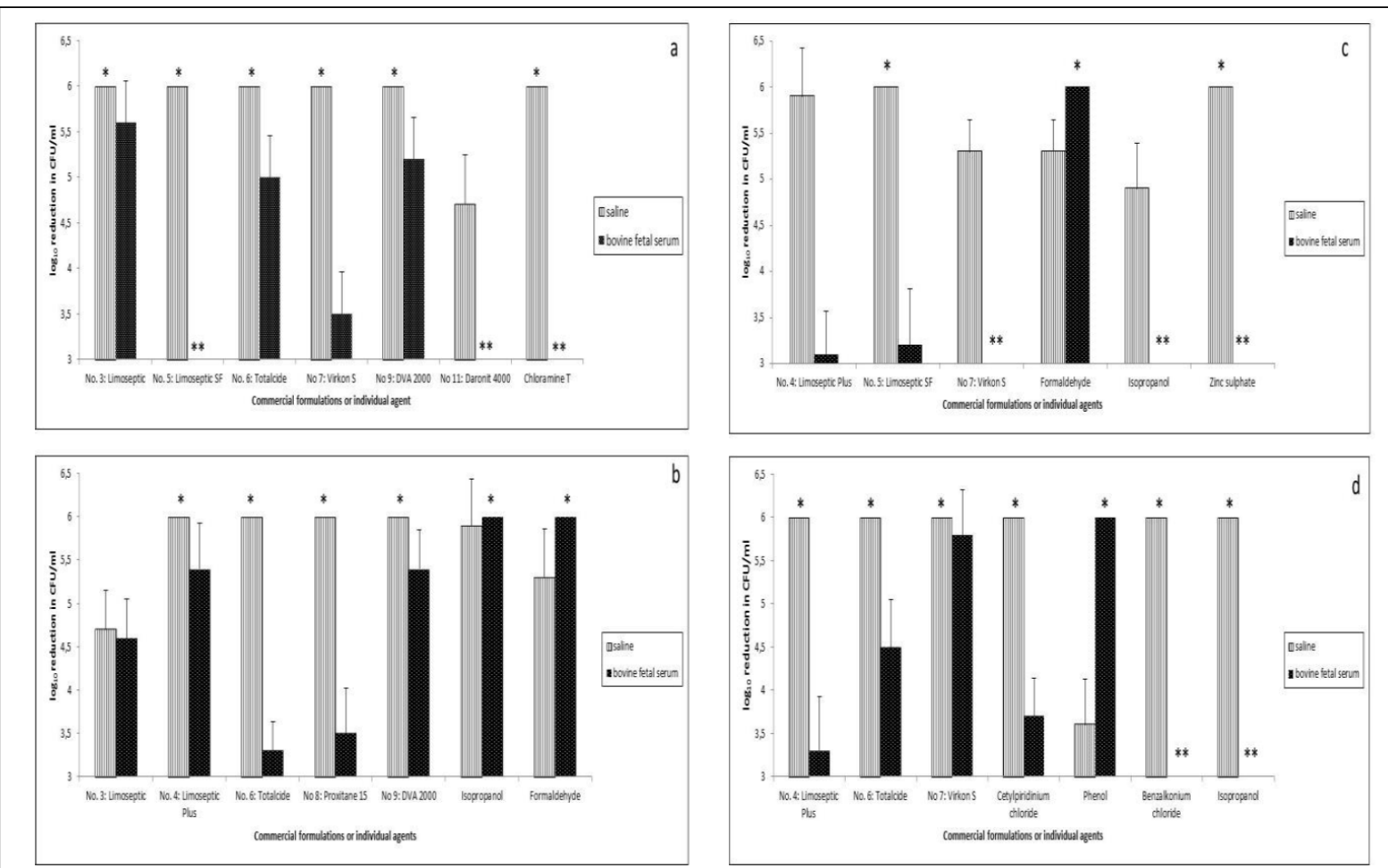

Figure 1 - Activities (expressed as from more than 3-log to 6-log reductions in CFU) caused by commercial formulations or individual agents against Salmonella enteritidis ATCC 13076 (a), S. enteritidis Le-01 (b), Escherichia coli $\mathrm{C}_{12} \mathrm{P}_{19}(\mathrm{c})$ and $\boldsymbol{E}$. coli $\mathrm{C}_{12} \mathrm{P}_{17}$ (d). Commercial formulations or individual agents showing the maximal effective level $(>6-\log )$ and those being ineffective $(<3-\log )$ for each strain under any conditions tested are not expressed in this figure.

*indicates activities higher than 6-log (the maximal level of detection: $99.9999 \%$ effectiveness); ${ }^{* *}$ indicates less than $3-\log$ reduction in assay, being the compound considered as inactive.

A similar figure was observed for benzalkonium chloride, but it was only active to $\mathrm{C}_{12} \mathrm{P}_{17}$ strain and zinc sulphate against $\mathrm{C}_{12} \mathrm{P}_{19}$ strain $+\mathrm{SS}$.

Among chlorine halogens, chloramine-T was only effective to one of $\boldsymbol{S}$. enteritidis strains with SS. However, this agent was not inactivated by BFS on Campylobacter jejuni (GUTIÉRREZ MARTÍN et al., 2011). Although $0.5 \%$ sodium hypochlorite was ineffective for $1 \mathrm{~min}$, a capability considerably superior in reducing both $\boldsymbol{E}$. coli and Salmonella was seen on broiler carcasses when acting for 1 hour (RUSSELL\& AXTELL, 2005). Therefore, a longer exposure time and/or a higher concentration probably might have been effective in this study. The fact that iodophor releasing $0.1 \%$ iodine was inactive could be justified by the different concentration of the active compound. In fact, the opposite result was obtained for povidoneiodine, which released a concentration 10-fold higher. In previous studies, iodine preparations were moderately active (McLAREN et al., 2011) or fully ineffective to Salmonella (KASSAIFY et al., 2007). Earlier reports stated that halogens are inhibited by organic debris (McLAREN et al., 2011), which is in disagreement with our results.

Hydrogen peroxide was inactive, unlike Proxitane 15 (Figure 1b), and this difference could be explained by the higher hydrogen peroxide concentration and/or the combination of two other oxidizing agents in compound 8. In accordance with our results, similar or lower hydrogen peroxide concentrations were insufficient to eradicate $\boldsymbol{S}$. virchow (NASSAR et al., 1997) or S. enteritidis (MARIN et al., 2009). Potassium permanganate was highly effective but the activity of Virkon S, composed of several potassium derivatives, decreased substantially with BFS (Figure 1a). EL-NAGGAR et al. (2001) reported that this commercial compound 
inactivated $\boldsymbol{E}$. coli after $5 \mathrm{~min}$ of contact at the same concentration used by this research, which indicated that an exposure to Virkon $\mathrm{S}$ is not necessary to inactivate $\boldsymbol{E}$. coli.

Benzalkonium and cetylpiridinium chlorides were more effective to $\boldsymbol{S}$. enteritidis than to $\boldsymbol{E}$. coli; in this respect, several resistance genes to quaternary ammonium compounds (QACs) have been reported in Gram-negative species (SILVER et al., 2000). Unlike our results, those by AARESTRUP \& HASMAN (2004) showed that Salmonella was more resistant to benzalkonium chloride than $\boldsymbol{E}$. coli. Although QAC-based formulations 1 and 2 resulted in maximal activity $\left(>6-\log _{10}\right)$ in this study, QACs have been considered only moderately effective to Salmonella (McLAREN et al., 2011).

S. enteritidis demonstrated a better susceptibility to isopropanol than $\boldsymbol{E}$. coli but, surprisingly; the combination of isopropanol and $p$-chlorometacresol in formulation 12 was not effective to any of the four isolates tested. This could be explained by the considerably lower concentration of isopropanol in this formulation or by the blend with cresol. Conversely, the high chlorhexidine digluconate activity was in agreement to that described for other Gramnegative organisms (GUTIÉRREZ MARTÍN et al., 2011). Contrarily to our results, STRINGFELLOW et al. (2009) reported that organic matter decreased considerably the efficacy of chlorhexidine against S. typhimurim.

Excellent capability of formaldehyde to kill the four strains is in line with that previously reported for Salmonella (McLAREN et al., 2011) and $\boldsymbol{E}$. coli (EL-NAGGAR et al., 2001). However, its use at lower concentrations was considered to be insufficient to completely eradicate Salmonella (MARIN et al., 2009). The high efficacy reported with phenol and UCI 414 is in accordance with some studies (KASSAIFY et al., 2007) but not with others (STRINGFELLOW et al., 2009). The four enterobacteria were not susceptible to phosphoric acid in our report, in contrast with the high effectiveness described for other Gram-negative organisms (GUTIÉRREZ MARTÍN et al., 2011).

Disinfection must be based on the selection of cheap, odorless and innocuous compounds, easy to be applied and highly effective after short exposures. Therefore, of the 28 individual or blended disinfectants compared in this in vitro model, ethanol, chlorhexidine digluconate, or commercial formulations 1,2 or 10 were the most effective against the four strains of $\boldsymbol{E}$. coli $/ \boldsymbol{S}$. enteritidis tested. Nevertheless, further in vivo studies are needed to confirm these in vitro results as the efficacy of a given disinfectant is influenced by several environmental factors.

\section{ACKNOWLEDGEMENTS}

This study was financed by the contract Evaluación de sistemas de reducción de la carga microbiana from the Instituto Tecnológico Agrario de Castilla y León (ITACYL), Consejería de Agricultura y Ganadería, Junta de Castilla y León, Spain.

\section{REFERENCES}

AARESTRUP, F.M.; HASMAN, H. Susceptibility of different bacterial species isolated from food animals to copper sulphate, zinc chloride and antimicrobial substances used for disinfection. Veterinary Microbiology, v.100, p.83-89, 2004.

EL-NAGGAR, M.Y.M. et al. Evaluation of in vitro antibacterial activity of some disinfectants on Escherichia coli serotypes. Journal of General and Applied Microbiology, v.47, p.63-73, 2001.

GUTIÉRREZ, C.B. et al. Efficacy of a variety of disinfectants against Actinobacillus pleuropneumoniae serotype 1. American Journal of Veterinary Research, v.56, p.1025-1029, 1995.

GUTIÉRREZ MARTÍN, C.B. et al. Evaluation of efficacy of several disinfectants against Campylobacter jejuni strains by a suspension test. Research in Veterinary Science, v.91, p.e44-e47, 2011. Available from: <http://www.ncbi.nlm.nih. gov/pubmed/?term=campylobacter+jejuni+Guti\%C3\%A9rre z+Mart\%C3\%Adn>. Accessed: Feb. 19, 2011. doi: 10.1016/j. rvsc. 2011.01 .020

JOHNSON, T.J. et al. Prevalence of avian-pathogenic Escherichia coli strain $\mathrm{O} 1$ genomic islands among extraintestinal and commensal $\boldsymbol{E}$. coli isolates. Journal of Bacteriology, v.194, p.2846-2853, 2012. Available from: <http://www.ncbi.nlm.nih. gov/pubmed/22467781>. Accessed: Mar. 30, 2012. doi: 10.1128/ JB.06375-11. Epub 2012 Mar 30.

KASSAIFY, Z.G. et al. Preliminary study on the efficacy and safety of eight individual and blended disinfectants against poultry and dairy indicator organisms. Veterinaria Italiana, v.43, p.821-830, 2007

MARIN, C. et al. Biofilm development capacity of Salmonella strains isolated in poultry risk factors and their resistance against disinfectants. Poultry Science, v.88, p.424-431, 2009. Available from: <http://www.ncbi. nlm.nih.gov/pubmed/?term=MARIN $+\mathrm{C}+$ and + Biofilm + an d+Salmonella>. Accessed: Mar. 30, 2012. doi: 10.3382/ ps.2008-00241.

McLAREN, I. et al. Evaluation of commonly-used farm disinfectants in wet and dry models of Salmonella farm contamination. Avian Pathology, v.40, p.3342, 2011. Available from: <http://www.ncbi.nlm.nih. 
gov/pubmed/21331946>. Accessed: Mar. 30, 2012. doi: $10.1080 / 03079457.2010 .537303$.

NASSAR, T.J. et al. Decontamination of chicken carcasses artificially contaminated with Salmonella. Revue Scientifique et Technique, v.16, p.891-897, 1997.

RUSSELL, S.M.; AXTELL, S.P. Monochloramine versus hypchlorite as antimicrobial agents for reducing populations of bacteria on broiler chicken carcasses. Journal of Food Protection, v.68, p.758-763, 2005.
SILVER, S. et al. Mechanisms of resistance to heavy metals and quaternary amines. In: FISCHETTI, V.A. et al. Gram-positive pathogens. Washington, DC: ASM, 2000. p.647-659.

STRINGFELLOW, K. et al. Evaluation of disinfectants commonly used by the commercial poultry industry under simulated field conditions. Poultry Science, v.88, p.1151-1155. 2009. Available from: <http://ps.oxfordjournals.org/content /88/6/1151.full.pdf + html $>$. Accessed: Mar. 30, 2012. doi: $10.3382 /$ ps.2008-00455. 